\title{
Evaluation of four plants compost teas against fungi responsible for Corn damping-off in Côte d'Ivoire
}

\author{
Soro Kouo-N'Golo ${ }^{1}$, Daniel Kra Kouamé 2 and Hortense Atta Diallo ${ }^{3}$ \\ Unité Santé des Plantes, Université Nangui Abrogoua, Côte d'Ivoire \\ belebox@yahoo.fr
}

\begin{abstract}
Corn (Zea mays L.) is one of the most important cereals in Côte d'Ivoire. However, Corn seeds and seedlings are susceptible to infection by a number of soilborne fungi which caused seeds decay before or after germination. The objective of this study is to evaluate the suppressive effect of Four plants compost teas (Chromolaena odorata, Ricinus communis, Nicotiana tabacum, Azadiracta indica) on Corn damping off. In vitro assays showed a most suppressive effect of $C$. odorata and $R$. communis compost teas on mycelial growth of pathogenic fungi. Results of in vivo trials showed significant reduction of Corn seedlings diseases incidence and high seed germination percent after treatment with $C$. odorata, $R$. communis and A. indica compost teas. No efficiency effect was noted with $N$. tabacum compost tea. This study demonstrated the usefulness of compost tea as an efficient biological tool for the control of fungi responsible of corn damping-off.
\end{abstract}

Keywords-Corn, damping-off, fungi, compost tea.

\section{INTRODUCTION}

Corn (Zea mays L.) is an annual tropical herbaceous plant of the family Poaceae and it is one of the most important cereal grains grown worldwide. Corn is the world's top most cereal crop in terms of total production and productivity after wheat and rice (FAO, 2006). Corn is the second most important food crop in Côte d'Ivoire after rice with an annual production of about 600000 tones (FAO, 2014). This commodity is widely grown for its starch-rich grains. It is also used as a forage plant in some localities. Corn is also the principal staple cereal diet of most of the Ivorian people who mainly lives in the North. In the last twenty years, Corn cultivation has experienced a considerable development of its market with urbanization and especially the establishment of food industries (Boone et al., 2008)

However, several diseases are observed on Corn and cause significant yield reduction (Sétamou et al., 1998). This decrease in yield is linked to the action of certain fungi that can have adverse effects on the aerial organs (ears, leaves and stems) or on the root system thus reducing the productivity of the plant. According to Harvey et al (2006), fungi such as Aspergillus sp., Pythium sp., Fusarium sp. and Rhizoctonia sp. would be responsible for root rot and seeding of corn.

Synthetic fungicides remain the most widely used control measure against fungal plant diseases. Although relatively effective, synthetic fungicides have two major drawbacks: their generally widespread lack of long-term efficacy caused by the development of resistance in plant pathogens (Avis, 2007). The fungicides, however, can have a negative effect on human health and the environment (Perez-Garcia et al. 2011)

A possible alternative to synthetic chemical fungicides is to exploit the antimicrobial activities of compost teas. The potential of compost tea in the suppression of plant pathogens has been demonstrated (Litterick et al., 2004). Recently, compost teas from sheep manure compost showed antimicrobial activities against phyllosphere (Koné et al., 2010) and rhizosphere (Dionne et al., 2012) pathogens of tomato (Solanum lycopersicum L.) plants. In addition, Compost teas was considered safer for health and the environment (Siddiqui et al., 2009).

The objective of this study is to identify the fungi responsible of seed-borne fungi in Corn seeds collected from different areas and evaluate compost tea of four plants on some fungal pathogens.

\section{MATERIALS AND METHODS}

\subsection{SAMPLING AND ISOLATION OF FUNGI}

Samples of ungerminated corn kernel showing rot symptom were removed 15 days after planting from Corn fields in three cultivation areas of Northern Côte d'Ivoire (Katiola, Korhogo, Odienne). Samples were transported to the laboratory for fungi isolation. To obtain fungal population from rotten Corn kernel, samples were disinfested in $2 \%$ sodium hypochlorite for $3 \mathrm{~min}$, rinsed twice in distilled water for $5 \mathrm{~min}$ and air-dried at $26^{\circ} \mathrm{C}$ for 1 to $2 \mathrm{~h}$ in a sterile Lamina flow hood. Sterilized kernels were placed into Petri dishes contained PDA medium, each 
medium containing 3 kernels was incubated at $28 \pm 2^{\circ} \mathrm{C}$. Mycelial growths from the corn kernel were transferred (picked with flamed needle from the periphery of growth) to fresh PDA plates. Sub-culturing was carried out to obtain pure isolates which were maintained on PDA. To confirm the identification of isolated fungi, microscopic observation of the morphological characteristics of the isolates, grown for two weeks in Petri dishes containing Potato Dextrose Agar (PDA), was performed using identification keys (Botton et al. 1990, Barry and Barnett, 1972). The frequency of each is olated fungi was calculated by using the following formula (1)

$$
\mathrm{F}(\%)=\frac{\mathrm{Nc}}{\mathrm{Nt}} \times 100
$$

Where, F: Frequency (\%), Nc: Number of genus or species isolated, $\mathbf{N t}$ : total number of isolates

\subsection{PATHOGENICITY TEST \\ 1.2.1. INOCULATION OF SEEDS}

Isolated fungi were analysed for their capacity to inhibit seed germination and the development of roots. Briefly, kernels corn was surface-disinfected for $3 \mathrm{~min}$ in $2 \%$ sodium hypochlorite, rinsed twice with distilled water. Corn kernels were immersed for 1mimute in a $10^{6} \mathrm{~mL}^{-1}$ micro conidial suspension and placed into Petri dishes on sterile water saturated filter paper. three dishes containing 15 seeds each were used for each isolated fungi and uninoculated seeds were used as controls. After 8 days, disease symptoms were estimated by determining the percentage of germinated seeds.

\subsection{EVALUATION OF ANTIFUNGAL ACTIVITY OF COMPOST TEA}

\subsubsection{PREPARATION OF COMPOST TEA}

Four extracts prepared from different compost $\left(\mathrm{C}_{1}, \mathrm{C}_{2}\right.$, $\mathrm{C}_{3}$, and $\mathrm{C}_{4}$ ) were used (Table1). Original composts were produced according to an aerobic process (Znaidi, 2002). Extract production consists on suspending composts in tap water $(1: 5, \mathrm{v} / \mathrm{v})$ in 20 litter plastic container and stirring the mixture daily for about $10 \mathrm{~min}$ during an extraction period of 5 days (Weltzein, 1992). After the incubation period, the mixture was filtered through cheesecloth $(250$ $\mu \mathrm{m})$ and the obtained extract were stored at $4{ }^{\circ} \mathrm{C}$.

\begin{tabular}{ll} 
& Table.1: compost ingredients \\
\hline Composts & \multicolumn{1}{c}{ Compositions } \\
\hline $\mathbf{C}_{1}$ & $20 \% \mathrm{Cm}+80 \%$ Chromolaena \\
& odorata leaves \\
$\mathbf{C}_{2}$ & $20 \% \mathrm{Cm}+80 \%$ Ricinus \\
& communis leaves \\
$\mathbf{C}_{3}$ & $20 \% \mathrm{Cm}+80 \%$ Azadirachta \\
& indica leaves \\
$\mathbf{C}_{4}$ & $20 \% \mathrm{Cm}+80 \%$ Nicotiana \\
& tabacum leaves \\
\hline
\end{tabular}

1.3.2. EFFECT OF COMPOSTS TEAS ON THE MYCELIAL GROWTH OF CORN DAMPING-OFF FUNGI

Antifungal activity of compost tea was evaluated using three fungi cultured on agar plates at concentration $60 \mathrm{~g} \mathrm{~L}^{-1}$ and unamended media were used as controls. The prepared composts teas were added to conical flasks containing previously sterilized and cooled agar medium. After thorough mixing, $15 \mathrm{~mL}$ of media were poured into sterilized Petri dishes $9 \mathrm{~cm}$ in diameter. Fungal plugs $(0.5 \mathrm{~mm}$ in diameter) were removed with a cork borer from the growing margin of each fungus colony and placed at the center of the test plate. Five replications were made for each treatment and the cultures were incubated at room temperature. Colony diameter was measured in two directions daily until the fungus covered the whole of the agar in the control plate. Data were expressed as growth rate $(\mathrm{mm} /$ day) relative to control. Percentage inhibition (mycelial growth) was determinate.

\subsubsection{IN VIVO EFFECT OF COMPOST TEAS AGAINST KERNEL CORN PATHOGENS}

Corn seeds were disinfected for $3 \mathrm{~min}$ in $2 \%$ sodium hypochlorite and rinsed with sterile distilled water. After drying, seeds were placed understerile conditions in Petri plates on filter papers soaked with sterile distilled water. Seed germination was assessed after 4 days in a growth chamber at $27{ }^{\circ} \mathrm{C}$ (Hibar et al., 2005). For each fungal pathogen, germinated seedlings were drenched with $100 \mathrm{ml}$ of conidia suspension $\left(10^{6}\right.$ conidia $\left.\mathrm{mL}^{-1}\right)$. For noninoculated control distilled water was used. Then inoculated seedlings were transferred to plastic pots filled with the following substrates: $\mathrm{T}_{0}$ : CMS (Corn Meal Agar) $+20 \mathrm{~mL}$ of distilled water (control), $\mathrm{T}_{1}$ : CMS+20 mL of $\mathrm{C}_{1}$, $\mathrm{T}_{2}: \mathrm{CMS}+20 \mathrm{~mL}$ of $\mathrm{C}_{2}, \mathrm{~T}_{3}: \mathrm{CMS}+20 \mathrm{~mL}$ of $\mathrm{C}_{3}, \mathrm{~T}_{4}: \mathrm{CMS}$ $+20 \mathrm{~mL}$ of $\mathrm{C}_{4}$. The experiment was carried out in a growth chamber at $27^{\circ} \mathrm{C}$ with a 12 - hour-photoperiod. For each treatment 15 pots were used and 3 seeds were planted per pots. Seedlings were watered daily. As a measure of disease severity, seedling stands were counted 25 days after inoculation. Low percent seedling stands indicated high disease severity, whereas high percent-seedling stands indicated high disease suppressiveness. Percentseedling stands were calculated and the mean value of five replications was considered.

\subsection{STATISTICAL ANALYSIS}

Means and standard error of the mean were calculated for the mycelial growth inhibition and germinated seeds after composts teas treatment measured for the three sets of experiments in each case. These means were statistically compared using the LSD Fischer test was used to determine if they were significantly different at $P$ $<0.05$.

$\mathrm{Cm}$ : Cattle manure 


\section{RESULTS}

\subsection{Identification and frequency of isolated fungi}

In total, seven fungal genera as sociated with corn kernel rot was isolated on PDA medium and were identified based on the morphologic and cultural characteristics as Aspergillus sp, Colletotrichum sp, Fusarium sp, Pythium sp, Rhizoctonia sp, Rhizomucor sp, Trichoderma sp.Trichoderma sp. was the most commonly isolated fungal species among all of the isolates obtained $(48.06 \%)$ followed by Fusarium sp. (34.73\%) and Rhizoctonia sp (13.53\%). Aspergillus sp (3.42\%) and Colletotrichum $(6.23 \%)$ had the lowest isolation rates (Figure 1).

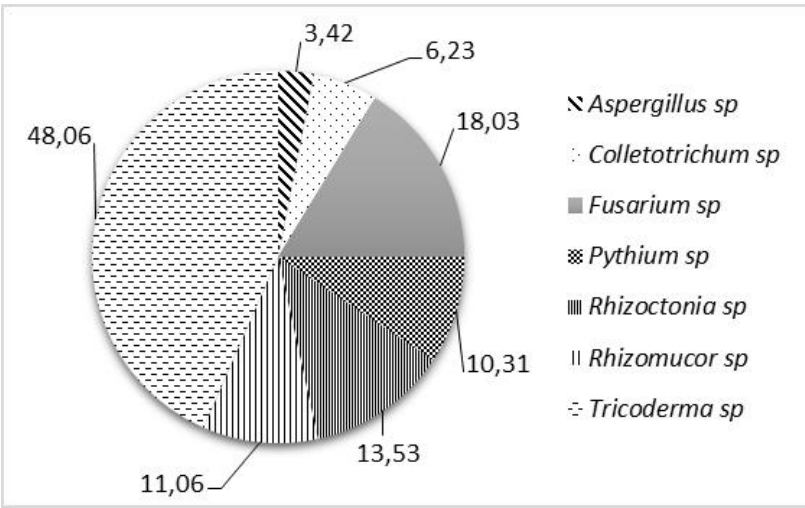

Fig.1: Proportion offungal species in the mycoflora of Corn grain

\subsection{PATHOGENICITY TESTS}

The pathogenicity test with fungi associated with corn kernel rot was carried out. Results based on the in vitro seeds inoculation test showed significant pathogenic effects of Pythium, Fusarium and Rhizoctonia on seeds germination and seedlings health due to high infection. Pythium sp and Rhizoctonia reduced significantly seeds germination with percentage germination of 5 and $2 \%$ respectively. Seeds infected by Fusarium sp showed percentage germination of 55\%. The seed samples inoculated with Aspergillus sp, Colletotrichum sp, Rhizomucor sp and Trichoderma sp showed similar percentage germination with the control seeds (Figure 2).

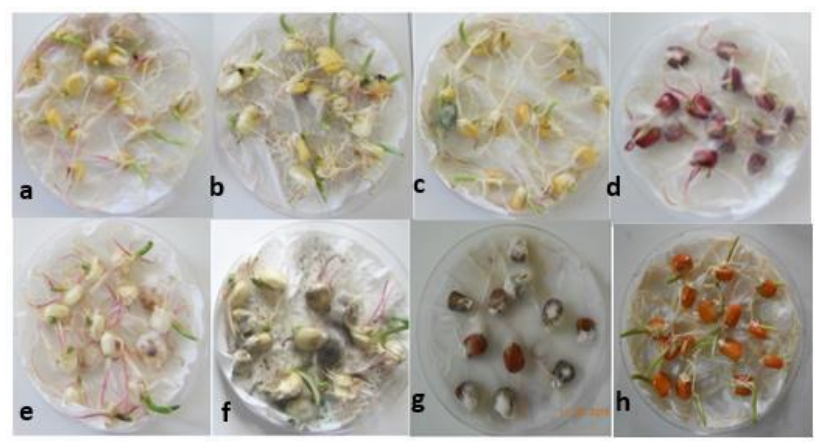

Fig.2: Fungi virulence assay on corn seed

a: Rhizomucor sp, b: Colletotrichum sp, c: Aspergillus sp, d: Fusarium sp, e:Trichoderma sp, f: Pythium sp, g: Rhizoctonia sp, h: control

\subsection{SUPPRESSION OF MYCELIAL GROWTH BY PLANTS COMPOST TEA}

Results showed that the tested compost teas induced a significant interaction with the tested phytopathogenic fungi. The radial growth of Pythium, Rhyzoctonia and Fusarium noted after 7 days of incubation, was significantly $(\mathrm{p}<0.05)$ reduced in compararison to the controls. In fact, Chromolaena odorata $\left(\mathrm{C}_{1}\right)$ and Ricinus communis $\left(\mathrm{C}_{2}\right)$ compost tea reduced significantly mycelial growth of all tested fungi with inhibition rates ranged from 85 to $100 \%$. The compost tea $\mathrm{C}_{3}$ was also effective against Rhizoctonia sp and Fusarium sp with inhibition ratios of 94.09 and $95.78 \%$ respectively. Compost tea $\mathrm{C}_{4}$ showed the less inhibitory effect reducing mycelial growth of Pythium and Fusarium by approximately 45 and $50 \%$ respectively (Table 2 ).

Table.2: In vitro effect of compost teas on mycelial growth of Pythium, Rhizoctonia, Fusarium

\begin{tabular}{|l|l|l|l|}
\hline \multirow{2}{*}{$\begin{array}{l}\text { Compost } \\
\text { teas }\end{array}$} & \multicolumn{4}{|l|}{ Mycelial inhibition rate (\%) } \\
\cline { 2 - 4 } & Pythium & Rhyzoctonia & Fusarium \\
\hline $\mathbf{C}_{\mathbf{0}}$ & $34,59 \pm 5,30^{\mathrm{e}}$ & $22,36 \pm 2,63^{\mathrm{c}}$ & $43,33 \pm 2,88^{\mathrm{d}}$ \\
\hline $\mathbf{C}_{\mathbf{1}}$ & $92,82 \pm 1,93^{\mathrm{a}}$ & $94,09 \pm 1,93^{\mathrm{b}}$ & $97,46 \pm 0,00^{\mathrm{b}}$ \\
\hline $\mathbf{C}_{\mathbf{2}}$ & $85,23 \pm 1,93^{\mathrm{b}}$ & $96,62 \pm 1,46^{\mathrm{b}}$ & $100,0 \pm 0,00^{\mathrm{a}}$ \\
\hline $\mathbf{C}_{\mathbf{3}}$ & $65,40 \pm 7,30^{\mathrm{c}}$ & $94,09 \pm 1,46^{\mathrm{b}}$ & $95,78 \pm 1,46^{\mathrm{b}}$ \\
\hline $\mathbf{C}_{\mathbf{4}}$ & $45,56 \pm 3,34^{\mathrm{d}}$ & $100,00 \pm 0,00^{\mathrm{a}}$ & $50,21 \pm 6,97^{\mathrm{c}}$ \\
\hline $\mathbf{F}$ & 10.42 & 8.40 & 10.35 \\
\hline $\mathbf{P}$ & 0.015 & 0.038 & 0.015 \\
\hline
\end{tabular}

Within a column, means with the same letter are not significantly different according to Fisher's LSD test $(P=$ $0.05)$.

\subsection{IN VIVO EVALUATION OF THE EFFECT OF COMPOSTS ON CORN KERNELS GERMINATION}

The percentage germination of corn kernels varied significantly according to compost tea treatments. In fact, the lowest percentage germination ranged from 16.29 to $53 \%$ was observed on the inoculated soil without compost tea treatment $\left(\mathrm{T}_{0}\right)$ and soil treated with nicotiana tabacum compost $\left(\mathrm{T}_{4}\right)$ (Table 3 ). In these subtract seedling showed disease symptoms include rotted seed that is soft and brown, rotted roots with a wet and slimy appearance. Above ground symptoms include damping-off after emergence and seedlings that turn yellow, wilt and die. Results recorded on inoculated soil treated with $C$. odorata and $R$. communis compost showed highest percentage germination (100\%). C. odorata and R. communis exhibited remarkable potency in suppressing seeds rot and seedling blight (Figure 3). 
Table.3: In vivo effect of compost teas on corn kernels germination.

\begin{tabular}{|c|c|c|c|}
\hline \multirow{2}{*}{$\begin{array}{c}\text { Compost } \\
\text { teas } \\
\text { treatment }\end{array}$} & \multicolumn{3}{|c|}{ Germination rate (\%) } \\
\cline { 2 - 4 } & Pythium & Rhyzoctonia & Fusarium \\
\hline $\boldsymbol{T}_{\boldsymbol{0}}$ & $44,44 \pm 8,11^{d}$ & $16,29 \pm 3,39^{d}$ & $43,40 \pm 10,02^{c}$ \\
\hline $\boldsymbol{T}_{\boldsymbol{1}}$ & $100^{a}$ & $100^{a}$ & $100^{a}$ \\
\hline $\boldsymbol{T}_{\boldsymbol{2}}$ & $100^{a}$ & $100^{a}$ & $100^{a}$ \\
\hline $\boldsymbol{T}_{\mathbf{3}}$ & $91,11 \pm 8,01^{b}$ & $94,07 \pm 5,59^{b}$ & $95,55 \pm 5,87^{b}$ \\
\hline $\boldsymbol{T}_{\boldsymbol{4}}$ & $53,12 \pm 5,87^{c}$ & $43,70 \pm 5,59^{c}$ & $47,41 \pm 6,78^{c}$ \\
\hline
\end{tabular}

Within a column, means with the same letter are not significantly different according to Fisher's LSD test $(P=0.05)$.

$\mathrm{T}_{0}$ control; $\mathrm{T}_{1}: C$. odorata compost tea treatment $; \mathrm{T}_{2}: R$. communis compost tea treatment $; \mathrm{T}_{3}:$ A. indica compost tea treatment $; \mathrm{T}_{4}: N$. tabacum compost tea treatment

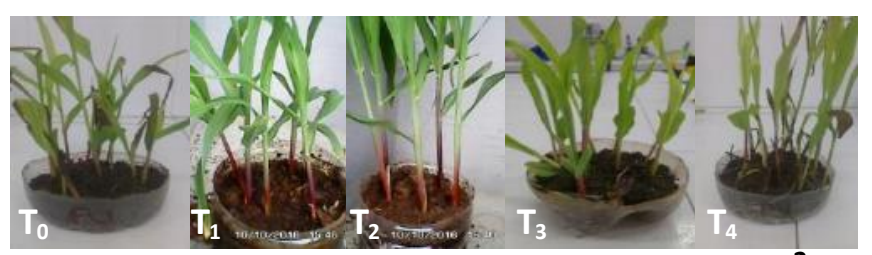

Fig.3: Corn seedlings diseases incidence after treatme $e^{2 \mathrm{~cm}}$ with compost teas

$\mathbf{T}_{\mathbf{0}}$ : Inoculated soil without compost tea treatment, $\mathbf{T}_{\mathbf{1}}: C$. odorata compost tea treatment $; \mathbf{T}_{\mathbf{2}}: R$. communis compost tea treatment $; \mathbf{T}_{\mathbf{3}}:$ A. indica compost tea treatment $; \mathbf{T}_{\mathbf{4}}: N$. tabacum compost tea treatment

\section{DISCUSSION}

Based on morphological characteristics, seven fungal genera were identified in total after isolation from corn kernels samples showing rot symptoms. These genera include Aspergillus sp, Colletotrichum sp, Fusarium sp, Pythium sp, Rhizoctonia sp, Rhizomucor sp, Trichoderma $\mathrm{sp}$. In this present study most of the obtained fungus genera (Colletotrichum sp, Rhizomucor sp, Trichoderma sp, Aspergillus sp) were saprophytic. Survey conducted by Niaz et al. (2009) showed that these fungi were frequently found in corn kernel. The abundant growth of saprophytic fungi on Corn seeds implies that storage problems should also be studied. It is now imperative that efforts should be made to continuously evaluate the seed health of Corn seeds produced in Côte d'ivoire. This current survey showed that Fusarium sp, Pythium sp and Rhizoctonia sp. induced corn kernel rot and seedling blight. Recent study conducted by Tesfaye and Dawit (1998) in Ethiopia showed that several phytopathogenic species included Fusarium spp were found to be associated with damaged corn kernel. (Girma, 2009) also identified Fusarium species associated with Corn grain in Ethiopia. Kommedahl (1981) observations revealed that symptoms caused by these pathogens are: failure to emerge, wilting, chlorosis or yellowing, root rot and poor rot development. Concerning Phythium sp, Zhang et al. (2000) confirms that a variety of Pythium spp. have the capacity to reduce germination and cause lesions on roots of corn and soybean seed and seedlings. Investigations conducted by Dorrance et al. (2004) showed that Pythium spp. frequently are as sociated with seed and seedling diseases, and commonly have been isolated from corn.

The aqueous extracts of composts leaf of Chromolaena odorata, Azadiracta indica and of Ricinus communis showed a more significant antifungal activity against Pythium sp., Rhyzoctonia sp. and Fusarium sp. Compost treatments significantly reduced the incidence of the disease on seed germination. No disease was observed in soils treated with Chromolaena odorata and Ricinus communis composts. Our results are in agreement with those obtained by Scheuerell and Mahaffee in 2004. These authors have shown that the irrigation by compost extract of a culture substrate inoculated with Pythium ultimum at reduces the effect of cucumber blight caused by this pathogen. The study conducted by El-Masry et al. (2002) showed that the compost extract can control several pathogenic fungi like Pythium debaryanum, Sclerotium bataticola and Fusarium oxysporum f. sp. lycopersici. In addition, Khaled et al. (2005) showed that the treatment of the growing medium, used for growing tomato plants, by the various compost extracts interfered with $F$. oxysporum infection. F. sp. radicis-lycopersici and its expression, which greatly reduced the incidence of the disease. Compost tea effectiveness could be explained by antifungal substances contained in leaves of each plant. Monisha et al. (2013) and Koumaglo et al. (2009) suggested that the aqueous extract of Chromolaena odorata and Ricinus communis leaves had antifungal properties due to the presence of compounds such as phenols, tannins and flavonoids. Le Page and Bousquet (2007) showed that several organic chemicals present in compost or released by compost inhabiting microorganisms provided disease suppressive effects, including phenolic compounds, volatile fatty acids and salicylic acid.

To summarize the present study showed that compost tea prepared from various plants leaves had negative effect on corn kernel pathogenic fungi (Fusarium sp, Pythium sp, Rhizoctonia sp). They could constitute a promising alternative for a biological control of seed and seedling diseases and reduces the abusive use of synthetic fungicides. However, a more field comprehensive survey is needed to confirm our findings in the field under natural conditions.

\section{REFERENCES}

[1] Avis, T.J., (2007). Antifungal compounds that target fungal membranes: applications in plant disease control. Can. J. Plant Pathol. 29, 323-329. 
[2] Barnett H.L. et Hunter B.B. (1972). Illustrated genera of imperfecti fungi.Third edition. Burgess Publishing Company.Minapolis, USA. 241 p.Biotechnol. 18:551-558.

[3] Boone P., Stathacos C.J.D. et Wanzie R.L. (2008). Evaluation sous régionale de la chaîne de valeurs du maïs, rapport technique ATP $\mathrm{N}^{\circ} 1$. Bethesda, MD : projet, Abt Associates Inc.

[4] Botton B., Breton A., Fevre M., Gauthier S., Guy P.H., Larpent J-P., Reymond P., Sanglier J-J., Vayssier Y., Veau P. (1990). Moisissures utiles et nuisibles, importance industrielle. Collection

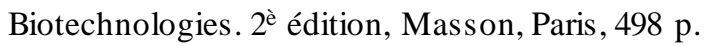

[5] Dionne, A., Tweddell, R.J., Antoun, H., Avis, T.J., (2012). Effect of non-aerated compost teas on damping-off pathogens of tomato. Can. J. Plant Pathol. 34, 51-57.

[6] Dorrance A.E, Jia H, Abeny T.S. (2004). Evaluation of soybean differentials for their interaction with Phytophthora sojae. Plant Health Prog. doi: 10.1094/PHP-2004-0309-01-RS.

[7] El-Masry M.H, Khalil A.I, Hassouna M.S, Ibrahim H.A.H. (2002). In situ and in vitro suppressive effect of agricultural composts and their water extracts on some phytopathogenic fungi. World J. Microbiol.

[8] FAO, (2006). FAOSTAT. Food and Agriculture Organization of the United Nations

[9] FAO, (2014). FAOSTAT. Food and Agriculture Organization of the United Nations

[10] Girma Tegegne, Fekede Abebe, Temam Hussien, Tewabech Tilahun, Eshetu Belete, Melkamu Ayalew, Girma Demese and Kiros Meles.(2009) (Eds). Review of Maize, Sorghum and Millet Pathology Research. In: Abraham Tadesse (Ed.), Increasing Crop Production through Improved Plant ProtectionVolume II.

[11] Harvey P.R. Warren R.A. et Wakelin S. (2006). Emerging soil-borne constraints to irrigated maize: a Pythium-fusarium root disease complex, 6th triennial conference, Maize Association of Australia, 8p

[12] Hibar, K., M. Daami-Remadi, H. Khaireddine and M. El Mahjoub. (2005). Effet inhibiteur In vitro et In vivo du Trichoderma harzianum sur Fusarium oxysporum f. sp. Radicis-lycopersici. Biotechnol. Agron. Soc. Environ., 9(3): 163-171.

[13] Kommedahl, T.; Windels, C.E. Root-, stalk-, and ear infection Fusarium species on corn in the USA. Fusarium (1981): Diseases, Biology, and Taxonomy; Pennsylvania State University: University Park, PA, USA;; pp 94-103.

[14] Koné, S.B., Dionne, A., Tweddell, R.J., Antoun, H., Avis, T.J., (2010). Suppressive effect of non-aerated compost teas on foliar fungal pathogens of tomato. Biol. Control 52, 167-173.
[15] Koumaglo K. H., Dotse K., Bettini F. et Bayle J.C. (2009). Chemical composition of Chromolaena odorata (L) King and Robinson (Asteraceae) essential oil from Togo: Drying and collecting site effects. $13 \mathrm{p}$

[16] Le Page C, Bousquet F (2007). Sustainable development and biodiversity - 2 , serie of Composing for Sustainable Agriculture (volume 3). M.L. Sukhadia University Botany Department, Udaipur, Rajasthan, India. Dinesh K. Maheshwari Editor.

[17] Litterick, A.M., Harrier, L., Wallace, P., Watson, C.A., Wood, M., (2004). The role of uncomposted materials, composts, manures, and compost extracts in reducing pest and disease incidence and severity in sustainable temperate agricultural and horticultural crop production - a review. Crit. Rev. Plant Sci. 23, 453-479.

[18] Monisha, K. (2013). Effect of Phytochemical Constituents of Ricinus Communis, Pterocarpus Santalinus, Terminalia Belerica on Antibacterial, Antifungal and Cytotoxic Activity International Journal of Toxicological and Pharmacological Research; 5(2): 47-54.

[19] Niaz, I.; Dawar, S. (2009) Detection of seed borne mycoflora in Corn (Zea mays L.). Pak. J. Bot., 41, 443-451.

[20] Perez-Garcia, A., Romero D., and A. de Vicente. (2011). Plant Protection and Growth Stimulation by Microorganisms: Biotechnological Applications of Bacillis in Agricultura." Current Opinion of Biotechnology 22: 187-193.

[21] Scheuerell, s.j., mahaffee, w.f. (2004). Compost tea as a container medium drench for suppressing seedling damping-off caused by Pythium ultimum. Phytopathology, 94, 1156-1163.

[22] Sétamou M, Cardwell K.F, Schulthess F et Hell K. (1998). Effect of insect damage to maize ears, with special reference to the ear borer Mussidiani grivenella, on Aspergillus flavusin fection and aflatoxin production in preharvest maize in the Republic of Benin. Journal of Economic Entomology, 91: 433-433.

[23] Siddiqui, Y., Meon, S., Ismail, R., Rahmani, M., (2009). Bio-potential of compost tea from agro-waste to suppress Choanephora cucurbitarum L. the causal pathogen of wet rot of okra. Biol. Control 49, 38-44.

[24] Tesfaye Woubet and Dawit Abate. (1998). Toxigenic Fusarium species in maize grain in Ethiopia. Pp.132134. In: Maize Production Technology for the future: Challenges and Opportunities. Proceedings of the 6th Eastern and Southern Africa Regional Maize Conference. CIMMYT/EARO. 
[25] Weltzien, H.C. (1992). Biocontrol of foliar fungal diseases with compost extracts. In: Micobial ecology of leaves. (Eds.): J.H. Andrews, S.S. Hirano. pp 430450. Springer Verlag, New York.

[26] Zhang, W., D.Y. Han, W.A. Dick, K.R. Davis H.A.J. Hoitink. (1998). Compost and compost water extract induced systemic acquired resistance in cucumber and Arabidopsis. Phytopathol., $88: 450-455$.

[27] Znaïdi, I.A. (2002). Etude et évaluation du compostage de différents types de matières organiques et des effets des jus de composts biologiques sur les maladies des plantes. Master of Science Degree $\mathrm{N}^{\circ}$ 286. Mediterranean Organic Agriculture, CIHEAM Mediterranean Agronomic Institute, $94 \mathrm{p}$. 